\title{
Fall Performance and Post-dormancy Growth of 'Midiron' Bermudagrass in Response to Nitrogen, Iron, and Benzyladenine
}

\author{
Richard H. White ${ }^{1}$ and Richard E. Schmidt ${ }^{2}$ \\ Soils and Crops Department, Rutgers University, New Brunswick, NJ 08903 \\ Additional index words. Cynodon dactylon, fertilization, turf quality, nonstructural carbohydrates
}

\begin{abstract}
Field research was conducted to determine the effects of $\mathrm{N}$, Fe, and benzyladenine (BA) on fall performance, post-dormancy recovery, and storage nonstructural carbohydrate composition of 'Midiron' bermudagrass [Cy nodon dactylon (L.) Pers.]. Fall green color retention and turf quality were superior for 48 than for $24 \mathrm{~kg}$ N/ha per month. Nitrogen level did not affect post-dormancy recovery or nonstructural carbohydrate levels in stolons and rhizomes measured in Sept. and Nov. 1983 and 1984. Iron level did not influence turf color and quality during summer months. Biweekly application of $0.6 \mathrm{~kg} \mathrm{Fe} / \mathrm{ha}$ produced better retention of greenness and turf quality during Fall 1983 and 1984 and superior turf color in Spring 1985 than the $0 \mathrm{~kg}$ Fe/ha treatment. Better green turf coverage was obtained with the biweekly than the monthly Fe (1.2 kg-ha-l) treatment during Fall 1983. In contrast, monthly Fe produced color and turf quality similar to that of the biweekly Fe treatment during Fall 1984. Nonstructural carbohydrates were similar among Fe levels in 1983 and 1984. The effects of Fe on turf color and quality were similar at each level of $\mathrm{N}$ and BA. BA level did not consistently influence turf color or quality and did not affect storage carbohydrate levels. When used in conjunction with moderate summer $\mathbf{N}$ fertilization, foliar-applied Fe can extend bermudagrass quality during fall without adversely affecting postdormancy recovery. Chemical name used: $N$ - (phenylmethyl)-lH-purin-6-amine (benzyladenine, BA).
\end{abstract}

Bermudagrass ceases growth and becomes discolored when exposed to chilling temperatures (3-5). Chilling stress occurs in grasses of tropical and subtropical origin at temperatures of 15 to $0 \mathrm{C}(12)$. Chilling injury of bermudagrass is characterized by the presence of necrotic lesions, chlorophyll loss, and subsequent leaf discoloration, and cessation of growth $(4,10,23)$. Disruption, of photosynthesis, respiration, and carbohydrate partitioning at chilling temperatures (21) contribute to reduced bermudagrass growth.

Pretreatment of 'Tifgreen' and 'Midiron' bermudagrass with $120 \mathrm{mg} \mathrm{Fe} / \mathrm{m}^{2}$ maintained a $23 \%$ higher average daytime $\mathrm{CO}_{2}$ exchange rate (CER) than within $0 \mathrm{mg} \mathrm{Fe} / \mathrm{m}^{2}$ after 4 days at a $10 / 7 \mathrm{C}$ chilling regime and following a 2-hr recovery period at $30 \mathrm{C}$ after exposure to chilling (21). Nighttime CER before and after the chilling regime was not significantly affected by Fe. However, average nighttime CER was 28\% higher for the 120 than the $0 \mathrm{mg} \mathrm{Fe} / \mathrm{m}^{2}$ treatment after recovery from chilling. Darker green turf color was observed for the 120 than for the $0 \mathrm{mg} \mathrm{Fe} / \mathrm{m}^{2}$ treatment after the chilling period, although no difference in chlorophyll content was detected among Fe treatments.

Iron deficiency in turf is often caused by factors that reduce the availability of $\mathrm{Fe}$ in soils and the ability of plants to take up and translocate sufficient amounts (19). Iron absorption and

Received for publication 18 Dec. 1988. Use of tradenames does not imply endorsement of products named or similar ones not mentioned. The cost of publishing this paper was defrayed in part by the payment of page charges. Under postal regulations, this paper therefore must be hereby marked advertisement solely to indicate this fact.

'Assistant Research Professor, Soils and Crops Dept., Cook College, RutgersThe State Univ. of New Jersey, New Brunswick, NJ 08903.

${ }^{2}$ Professor, Dept. of Agronomy, Virginia Polytechnic Institute and State Univ., Blacksburg, VA 24061. translocation in centipedegrass [Eremochloa ophiuroides (Munro.) Hack.] was inhibited when night temperatures fell from 18 to $25 \mathrm{C}$ down to -1 to $7 \mathrm{C}(20)$.

Cytokinins affect translocation of some nutrient elements. Kinetin at $1.5 \times 10^{-4} \mathrm{M}$ stimulated mass flow transport of ${ }^{32} \mathrm{P}$ in phloem of corn (Zea mays L.) leaves to the kinetin application area (14). Translocation of ${ }^{59} \mathrm{Fe}$ from a primary bean (Phaseolus vulgaris L.) seedling leaf to a trifoliate leaf was increased by treatment of the trifoliate with kinetin (9). Chilling temperatures may inhibit cytokinin biosynthesis in chill-sensitive plant species (2).

The objective of this study was to evaluate the effect of latesummer and fall foliar applications of $\mathrm{Fe}$ and BA in conjunction with summer $\mathrm{N}$ fertilization on bermudagrass performance during fall and on post-dormancy recovery in spring. The effects of $\mathrm{N}, \mathrm{Fe}$, and $\mathrm{BA}$ on nonstructural carbohydrate accumulation in bermudagrass storage tissues were also studied.

\section{Materials and Methods}

The 2-year study was initiated in June 1983 and continued through 1985 on a six-year-old 'Midiron' bermudagrass turf growing in a Groseclose silt loam (clayey, kaolinitic, mesic Typic Hapludult) soil, pH 5.7, at the Turfgrass Research Center at Blacksburg, Va. A multiple split-plot experimental design with four replications was used. Whole plots were $4.5 \times 3 \mathrm{~m}$ and consisted of monthly $\mathrm{N}$ fertilization treatments during June through September of 24 and $48 \mathrm{~kg} \mathrm{~N} / \mathrm{ha}$ from $\mathrm{NH}_{4} \mathrm{NO}_{3}$.

Sub-plots were $\mathrm{Fe}$ treatments consisting of 0 or $1.2 \mathrm{~kg} \cdot \mathrm{ha}^{-1}$ monthly, and $0.6 \mathrm{~kg} \cdot \mathrm{ha}^{-1}$ biweekly from sodium ferric diethylene triamine pentaacetate during the period of 15 July through 15 Oct. Sub-sub-plots were $1.5 \times 1.5 \mathrm{~m}$ and consisted of BA treatments of 0 and $0.062 \mathrm{~kg} \cdot \mathrm{ha}^{-1}$ applied every 2 weeks $(0.124$ $\mathrm{kg} \cdot \mathrm{ha}^{-1} \mathrm{month}^{-1}$ ) from 15 Aug. through 15 Oct. Nitrogen and 
Fe treatments were randomly arranged in rows and BA treatments were randomly arranged in column strips across $\mathrm{N}$ and Fe treatments within replications producing complete factorialization of treatments. A total of 48 plots was used. Fe and BA were applied using a compressed air boom sprayer that delivered 561 liters of aqueous solution/ha.

The plots were maintained at a $2.5-\mathrm{cm}$ height by mowing one or two times per week with a reel mower with clippings being returned. Irrigation was applied as needed to maintain favorable growing conditions. Phosphorus (treble superphosphate) and $\mathrm{K}$ (KC1), were applied each June at $97 \mathrm{~kg} \cdot \mathrm{ha}^{-1}$.

Visual ratings of bermudagrass color, taken at about weekly intervals, were based on $0=$ no green turf cover and $100=\mathrm{a}$ complete, uniform cover. Turf quality ratings were used as an indication of treatment effects on bermudagrass performance during the fall. Turf quality was based on $1=$ no live turf and $9=$ dark green, dense, uniform turf. Bermudagrass color taken following dormancy break in spring and clipping yields taken in May 1984 and 1985 were used to assess treatment effects on post-dormancy recovery.

Two soil cores $(10 \mathrm{~cm}$ in diameter $\times 10 \mathrm{~cm}$ deep) were collected at random from each plot on 30 Sept. and 24 Nov. 1983 and on 13 Sept. and 14 Nov. 1984. After washing soil from each core, samples were stored at $-8 \mathrm{C}$ until rhizome and stolon tissue could be collected by hand separation. Rhizome and stolon tissue was dried for $1 \mathrm{hr}$ at $100 \mathrm{C}$, then for $24 \mathrm{hr}$ at $65 \mathrm{C}$ in a forced-air oven. Tissue was then ground to pass a 40 mesh screen in a Cyclone Sample Mill (UD Corporation, Boulder, Colo.).

Rhizomes and stolons were analyzed for nonreducing and reducing sugars and starch (18) with modifications as outlined below. Water-soluble sugars were extracted by addition of 20 ml distilled $\mathrm{H}_{2} \mathrm{O}$ to $100-\mathrm{ml}$ test tubes containing 100-mg tissue samples and heating at 100C for $1 \mathrm{hr}$ in a water bath. Following this initial extraction, a 4-ml aliquot of extract was removed and replaced by $4 \mathrm{ml}$ of $0.8 \mathrm{~N} \mathrm{H}_{2} \mathrm{SO}_{4}$. Samples were returned to a $100 \mathrm{C}$ water bath. After $1 \mathrm{hr}$, a $4-\mathrm{ml}$ aliquot was again removed, and $8 \mathrm{ml}$ of enzyme-buffer solution was added. The enzyme-buffer solution contained $4 \mathrm{ml}$ of $15 \%$ takadiastase (Charase 40000, Miles Laboratories) and $4 \mathrm{ml}$ of buffer [2 parts $0.2 \mathrm{~N}$ acetic acid : 3 parts $0.2 \mathrm{~N}$ sodium acetate, $\mathrm{pH} 4.9$ (v/ v)]. Samples were then incubated for $24 \mathrm{hr}$ at 37C, after which a 4-ml aliquot was removed.

Reducing power of each 4-ml aliquot was immediately determined by automated colorimetric analysis following reaction with p-amino hydroxybenzoic acid hydrazide $(11,22)$. Nonreducing sugar content of tissue was taken as the difference in reducing power following incubation with dilute $\mathrm{H}_{2} \mathrm{SO}_{4}$ minus reducing power of the hot water extract. Starch content was taken as the difference in reducing power following enzyme digestion minus reducing power of the hot water extract. Carbohydrate content was expressed as glucose equivalents per kilogram of tissue.

All data were subjected to an analysis of variance. When a significant $\mathrm{F}$ ratio occurred for a treatment effect, a LSD was calculated.

\section{Results and Discussion}

Fall performance. The $48 \mathrm{~kg} \mathrm{~N} /$ ha treatment produced darker green, more-dense turf during June through early September than did plots fertilized with $24 \mathrm{~kg} \mathrm{~N} / \mathrm{ha}$ (data not shown). Subsequently, fall bermudagrass color retention was superior for the 48 than the $24 \mathrm{~kg} \mathrm{~N} / \mathrm{ha}$ treatment. Green turf coverage was better for the former on 30 Sept. and 24 Oct. 1983 and from 4 Oct. through 7 Nov. 1984 (Table 1). Because first- and second-order interaction effects involving $\mathrm{N}, \mathrm{Fe}$, and $\mathrm{BA}$ were not significant $(P<0.05)$, only the main effects of treatments are presented.

'Tifgreen' bermudagrass fertilized with $\mathrm{N}$ during the fall remained a darker green longer, but was more susceptible to frost injury than turf that received only summer $\mathrm{N}$ (16). Although $\mathrm{N}$ was applied no later than the 2nd week in September in both years of this study, differences in turf color were evident among $\mathrm{N}$ application levels until 24 Oct. 1983 and 7 Nov. 1984. The superior color retention was associated with higher turf quality scores for the 48 than the $24 \mathrm{~kg} \mathrm{~N} / \mathrm{ha}$ treatment until the 4th week of Oct. 1983 and the 2nd week of Oct. 1984 (Table 2).

No obvious visual differences in turf response to application levels of Fe occurred until September or October, when ambient air temperatures reached chilling or frost conditions (Fig. 1). A monthly application of $1.2 \mathrm{~kg} \mathrm{Fe} /$ ha helped retain more green turf coverage than the $0 \mathrm{~kg} \mathrm{Fe} / \mathrm{ha}$ treatment by 13 Oct. and 4 Nov. 1983 and during 4 Oct. through 7 Nov. 1984 (Table 1). The monthly Fe treatment did not effectively improve bermudagrass turf quality scores in Fall 1983 compared to the $0 \mathrm{~kg}$ $\mathrm{Fe} /$ ha treatment (Table 2). However, turf quality during Sept. and Oct. 1984 was higher for monthly Fe applications than for $0 \mathrm{~kg} \mathrm{Fe} / \mathrm{ha}$.

Greater green turf coverage was observed for the biweekly $0.6 \mathrm{~kg} \mathrm{Fe} / \mathrm{ha}$ treatment than for $0 \mathrm{~kg} \mathrm{Fe} / \mathrm{ha}$ during $30 \mathrm{Sept}$. through 4 Nov. 1983 and during 4 Oct. through 7 Nov. 1984 (Table 1). Better color retention by the biweekly Fe treatment compared to $0 \mathrm{~kg} \mathrm{Fe} / \mathrm{ha}$ resulted in superior turf quality scores for the former during Sept. and Oct. 1983 and 1984 (Table 2).

Green turf coverage was better with the biweekly than the monthly Fe treatment from 6 through 24 Oct. 1983 (Table 1). In contrast, the monthly $\mathrm{Fe}$ treatment produced green coverage similar to that of the biweekly Fe treatment during Fall 1984. The different response to timing of Fe application probably occurred because air temperatures declined more rapidly and earlier in Fall 1983 than in 1984 (Fig. 1).

BA tended to promote better color retention during Fall 1983 than in 1984 (Table 1). BA level did not influence fall turf quality in either year of this study (data not shown).

Post-dormancy growth. N application level the previous summer did not significantly affect post-dormancy recovery of 'Midiron' bermudagrass in 1984 or 1985 (data not shown). Increasing summer $\mathrm{N}$ fertilization rates decreased winter survival of coastal bermudagrass (1). However, bermudagrass recovery from winter damage was best with high-N fertilization in combination with high-K fertilization (8). Post-dormancy recovery of 'Midiron' was not affected by $\mathrm{N}$ application level, probably because the range of $\mathrm{N}$ rates used was narrow and considered moderate for bermudagrass turf. Also, 'Midiron' bermudagrass has good to excellent winter survival history in the mid-Atlantic United States (8).

BA treatment did not enhance post-dormancy recovery of 'Midiron' in Spring 1984 or 1985 (data not shown). However, a monthly application of $1.2 \mathrm{~kg} \mathrm{Fe} /$ ha during the previous fall produced more green turf coverage than the $0 \mathrm{~kg} \mathrm{Fe} / \mathrm{ha}$ treatment during 21 May to 25 June 1984 and during 15 Apr. to 6 June 1985 (Table 3). Monthly Fe applications stimulated more rapid development of bermudagrass green coverage in Spring 1984 than the biweekly Fe treatment. However, no significant difference in green coverage occurred in Spring 1985 among the monthly and biweekly Fe treatments. The biweekly Fe treat- 
Table 1. 'Midiron' bermudagrass color ratings during fall as influenced by summer $\mathrm{N}$ fertilization and $\mathrm{Fe}$ and BA application. ${ }^{\mathrm{z}}$

\begin{tabular}{|c|c|c|c|c|c|c|c|c|c|c|c|c|c|}
\hline \multirow{4}{*}{\multicolumn{2}{|c|}{$\begin{array}{c}\text { Application } \\
\text { level } \\
\text { Compound }\left(\mathrm{kg} \cdot \mathrm{ha}^{-1} \cdot \mathrm{month}^{-1}\right)\end{array}$}} & \multicolumn{12}{|c|}{ Color ratings ${ }^{y}$} \\
\hline & & \multicolumn{6}{|c|}{1983} & \multicolumn{6}{|c|}{1984} \\
\hline & & \multicolumn{2}{|c|}{ Sept. } & \multicolumn{3}{|c|}{ Oct. } & \multirow{2}{*}{$\frac{\text { Nov. }}{4}$} & \multicolumn{2}{|c|}{ Sept. } & \multicolumn{3}{|c|}{ Oct. } & \multirow{2}{*}{ Nov. } \\
\hline & & 15 & 30 & 6 & 13 & 24 & & 20 & 4 & 10 & 15 & 30 & \\
\hline \multicolumn{14}{|l|}{ Nitrogen } \\
\hline & 24 & 74 & 60 & 63 & 64 & 61 & 38 & 94 & 87 & 72 & 61 & 58 & 29 \\
\hline & 48 & 75 & 69 & 70 & 69 & 69 & 46 & 94 & 93 & 83 & 71 & 73 & 40 \\
\hline \multirow{4}{*}{$\begin{array}{l}\text { FLSD }_{0.05}{ }^{x} \\
\text { Iron }\end{array}$} & & NS & 5 & NS & NS & 7 & NS & NS & 4 & 7 & 9 & 13 & 8 \\
\hline & 0 & 69 & 62 & 62 & 61 & 60 & 30 & 93 & 87 & 65 & 51 & 56 & 22 \\
\hline & 1.2 & 70 & 64 & 65 & 66 & 62 & 46 & 95 & 92 & 85 & 77 & 74 & 41 \\
\hline & $0.6+0.6$ & 75 & 68 & 73 & 74 & 71 & 49 & 95 & 92 & 83 & 70 & 68 & 42 \\
\hline \multirow{3}{*}{$\begin{array}{l}\text { FLSD }_{0.05} \\
\mathrm{BA}\end{array}$} & & NS & 4 & 5 & 4 & 3 & 5 & NS & 3 & 6 & 7 & 5 & 4 \\
\hline & 0 & 71 & 62 & 65 & 65 & 63 & 39 & 95 & 90 & 75 & 63 & 64 & 35 \\
\hline & 0.124 & 75 & 67 & 69 & 68 & 66 & 45 & 94 & 90 & 81 & 69 & 68 & 34 \\
\hline FLSD $_{0.05}$ & & NS & 4 & 3 & NS & NS & 5 & NS & NS & 5 & NS & NS & NS \\
\hline
\end{tabular}

${ }^{2}$ Nitrogen, $\mathrm{Fe}$, and $\mathrm{BA}$ data are the means of 24,16 , and 24 observations, respectively. ${ }^{y}$ Color ratings: $100=$ complete green bermudagrass ground cover, $0=$ no green turf cover.

×FLSD, Fisher's LSD $(P \leq 0.05)$ for comparison of treatment means within compounds. NSNot significant.

Table 2. Turf quality of 'Midiron' bermudagrass during fall as influenced by summer $\mathrm{N}$ fertilization and $\mathrm{Fe}$ application. ${ }^{\mathrm{x}}$

\begin{tabular}{|c|c|c|c|c|c|c|c|c|c|}
\hline \multirow[b]{4}{*}{ Compound } & \multirow{4}{*}{$\begin{array}{c}\begin{array}{c}\text { Application } \\
\text { level }\end{array} \\
\left(\mathrm{kg} \cdot \mathrm{ha}^{-1} \cdot \text { month }^{-1}\right) \\
\end{array}$} & \multicolumn{8}{|c|}{ Turf quality } \\
\hline & & \multicolumn{4}{|c|}{1983} & \multicolumn{4}{|c|}{1984} \\
\hline & & \multicolumn{2}{|c|}{ Sept. } & \multicolumn{2}{|c|}{ Oct. } & \multirow{2}{*}{$\frac{\text { Sept. }}{20}$} & \multicolumn{3}{|c|}{ Oct. } \\
\hline & & 16 & 26 & 13 & 28 & & 3 & 10 & 29 \\
\hline \multicolumn{10}{|l|}{ Nitrogen } \\
\hline & 24 & 5.5 & 5.5 & 4.2 & 3.0 & 5.6 & 5.4 & 4.7 & \\
\hline & 48 & 6.4 & 6.0 & 4.8 & 3.6 & 6.5 & 6.9 & 5.8 & 5.2 \\
\hline $\mathrm{FLSD}_{0.05} \mathrm{x}$ & & 0.6 & NS & 0.5 & 0.4 & 0.5 & 0.7 & 0.4 & NS \\
\hline \multicolumn{9}{|l|}{ Iron } & 4.1 \\
\hline & 1.2 & 5.6 & 5.6 & 4.3 & 3.0 & 6.3 & 6.5 & 5.6 & \\
\hline & $0.6 \pm 0.6$ & 6.7 & 6.2 & 4.8 & 3.5 & 6.6 & 6.5 & 5.3 & 4.9 \\
\hline$F_{L S D} 0.05$ & & 0.3 & 0.4 & 0.4 & 0.3 & 0.5 & 0.3 & 0.3 & 0.6 \\
\hline
\end{tabular}

${ }^{2}$ Nitrogen, Fe, and BA data are the means of 24,16 , and 24 observations, respectively. ${ }^{y}$ FLSD $=$ Fisher's LSD $(P \leq 0.05)$ for comparison of treatment means within compounds.

xVisual quality: 9 = dark green, dense, uniform turf; $1=$ no live turf.

NSNot significant.

ments produced green turf coverage similar to the $0 \mathrm{~kg} \mathrm{Fe} / \mathrm{ha}$ treatment during Spring 1984, but the former was superior during Spring 1985.

Clipping yields were not significantly affected in May 1984 or 1985 by $\mathrm{N}, \mathrm{Fe}$, or BA levels. The significantly higher green turf coverage for the monthly compared to the biweekly $\mathrm{Fe}$ treatment without a corresponding increase in clipping yields appears contradictory. Iron applied in late September to common bermudagrass approaching the onset of dormancy had no effect on color ratings taken the following spring (13). 'Midiron' treated with Fe during summer and fall appeared to have darker green leaves in Spring 1984 and 1985 than 'Midiron' that received no $\mathrm{Fe}$ applications. This observation indicates that $\mathrm{Fe}$ applied the previous season may reduce chlorosis exhibited in bermudagrass turf in early spring under some environmental conditions. Because clipping yields did not differ significantly among Fe application levels, the differences in 'Midiron' green coverage during spring may have occurred primarily due to chlorosis in the $0 \mathrm{~kg} \mathrm{Fe} / \mathrm{ha}$ treatment.

Nonstructural carbohydrates. Total nonstructural carbohydrates (TNC) and nonstructural carbohydrate components were similar among levels of N, Fe, and BA (data not shown). TNC in stolons changed relatively little from Sept. to Nov. 1983, but increased by $15 \%$ during a similar sampling interval in 1984 (Table 4). Stolon starch levels decreased by $20 \%$ from Sept. to Nov. in 1983 and decreased 32\% during the same period in 1984. During this same period, reducing sugars increased $40 \%$ in 1983 and $144 \%$ in 1984, while nonreducing sugars increased $24 \%$ in 1983 and $275 \%$ in 1984.

Average rhizome TNC was similar during September and November for both years (Table 4). Similar to stolon starch levels, rhizome starch levels were $25 \%$ lower in 1983 and $29 \%$ 


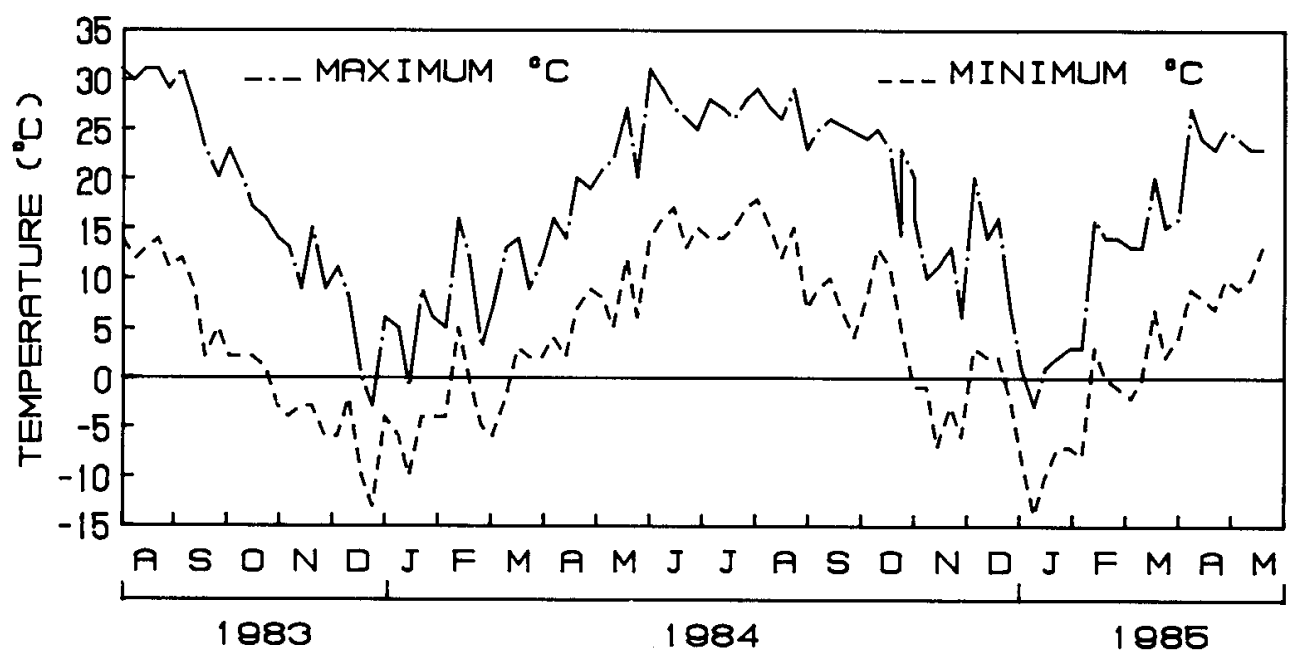

Fig. 1. Weekly average maximum and minimum temperature at Blacksburg, Va. during Aug. 1983 through May 1985.

Table 3. 'Midiron' bermudagrass color ratings and clipping yields during spring as influenced by Fe application. ${ }^{z}$

\begin{tabular}{|c|c|c|c|c|c|c|c|c|c|}
\hline \multirow{4}{*}{$\begin{array}{c}\text { Iron } \\
\text { application } \\
\text { level } \\
\left(\mathrm{kg} \cdot \mathrm{ha}^{-1} \cdot \text { month }^{-1}\right)\end{array}$} & \multicolumn{8}{|c|}{ Color ratings ${ }^{y}$} & \multirow{4}{*}{$\begin{array}{c}\begin{array}{c}\text { Cliping } \\
\text { dry wt. }\end{array} \\
1984-85\end{array}$} \\
\hline & \multicolumn{5}{|c|}{1984} & \multicolumn{3}{|c|}{1985} & \\
\hline & \multicolumn{3}{|c|}{ May } & \multicolumn{2}{|c|}{ June } & \multicolumn{2}{|c|}{ April } & \multirow{2}{*}{$\frac{\text { June }}{6}$} & \\
\hline & 7 & 14 & 21 & 10 & 25 & 15 & 30 & & \\
\hline 0 & 23 & 36 & 45 & 60 & 75 & 26 & 47 & 58 & 29 \\
\hline 1.2 & 29 & 47 & 56 & 70 & 84 & 33 & 55 & 66 & 29 \\
\hline $0.6+0.6$ & 25 & 39 & 48 & 63 & 78 & 33 & 56 & 67 & 28 \\
\hline FLSD $_{0.05}$ & NS & NS & 6 & 5 & 4 & 5 & 8 & 7 & NS \\
\hline
\end{tabular}

${ }^{2}$ Data are the means of 16 observations.

${ }^{y}$ Color ratings: $100=$ complete green bermudagrass ground cover, $0=$ no green turf cover.

${ }^{\times F L S D}=$ Fisher's LSD $(P \leq 0.05)$ for comparison of treatment means within compounds.

${ }_{\text {NSNot significant. }}$

Table 4. Average total nonstructural carbohydrates (TNC) and nonstructural carbohydrate components in 'Midiron' bermudagrass stolons and rhizomes during fall. ${ }^{2}$

\begin{tabular}{|c|c|c|c|c|c|c|c|c|}
\hline \multirow{3}{*}{$\begin{array}{l}\text { Data of } \\
\text { sampling }\end{array}$} & \multicolumn{4}{|c|}{ Stolons } & \multicolumn{4}{|c|}{ Rhizomes } \\
\hline & \multicolumn{2}{|c|}{$\begin{array}{r}\text { Sugars } \\
\end{array}$} & \multirow[b]{2}{*}{ Starch } & \multirow[b]{2}{*}{ TNC } & \multicolumn{2}{|c|}{ Sugars } & \multirow[b]{2}{*}{ Starch } & \multirow[b]{2}{*}{ TNC } \\
\hline & Nonreducing & Reducing & & & Nonreducing & Reducing & & \\
\hline 1983 & \multicolumn{8}{|c|}{$\left(g \cdot k g^{-1}\right)$} \\
\hline 30 Sept. & 21 & 92 & 135 & 249 & 17 & 90 & 184 & 291 \\
\hline 24 Nov. & 26 & 129 & 92 & 247 & 21 & 128 & 131 & 280 \\
\hline FLSD $_{0.05^{y}}$ & 3 & 13 & 16 & NS & NS & 15 & 21 & NS \\
\hline \multicolumn{9}{|l|}{1984} \\
\hline 13 Sept. & 8 & 45 & 231 & 283 & 7 & 47 & 311 & 366 \\
\hline 14 Nov. & 30 & 110 & 187 & 326 & 22 & 115 & 234 & 371 \\
\hline $\mathrm{FLSD}_{0.05}$ & 4 & 7 & 27 & 26 & 4 & 14 & 23 & NS \\
\hline
\end{tabular}

${ }^{2}$ Data are averages for 1983 and 1984.

${ }^{y}$ FLSD $=$ Fisher's LSD $(P \leq 0.05)$ for comparison of means within years.

NSNot significant.

lower in 1984 for the November than the September sampling. previously (6). In 'U-3', 'Midway', and 'Westwood' bermuRhizome reducing sugars increased $42 \%$ in 1983 and $145 \%$ in 1984, while nonreducing sugars increased by $24 \%$ in 1983 and $214 \%$ in 1984 from September to November. Similar increases dagrasses, starch levels gradually decreased, and reducing and nonreducing sugars increased slightly during late September to early December. Meyer zoysiagrass (Zoysia japonica Steud.) in TNC in three other bermudagrass cultivars were reported rhizomes and stolons accumulated TNC during September and 
remained near $50 \%$ of dry weight until December (17). Reducing sugars remained low and unchanged, while total sugars gradually increased during fall.

Conversion of starch to sugar and accumulation of maximum sugar levels in perennials acclimated to low temperatures have been suggested to favor winter survival by plants $(6,7,15)$. Accumulation of sugars in rhizome and stolon tissue may explain the relatively good winter survival exhibited by 'Midiron'. Because TNC levels were relatively high in stolons and rhizomes and TNC did not change dramatically during the sampling interval, TNC accumulation in 'Midiron' may not be as important to low temperature survival, as is the conversion of insoluble polysaccharides to water-soluble forms.

The results of this study indicate that, when used in conjunction with moderate summer $\mathrm{N}$ fertilization, foliar-applied Fe can improve the performance of bermudagrass during fall and hasten post-dormancy recovery in spring. The extension of bermudagrass performance during fall by Fe application does not adversely affect carbohydrate storage levels in bermudagrass rhizomes and stolons present at the onset of dormancy and does not appear to limit winter survival.

\section{Literature Cited}

1. Adams, E.W. and M. Twersky. 1960. Effect of soil fertility on winter killing of coastal bermudagrass. Agron. J. 52:325-326.

2. Atkin, R. K., G.E. Barton, and D.K. Robinson. 1973. Effect of root-growing temperature on growth substances in xylem exudate of Zea mays. J. Expt. Bet, 24:475-487.

3. Burton, G.W. 1966. Tifdwarf bermudagrass. Crop Sci. 6:94. 19.

4. DiPaola, J. M., K.J. Karnok, and J.B. Beard. 1981. Growth, color, and chloroplast pigment content of bermudagrass turfs under chilling conditions as influenced by gibberellic acid, p. 527534. In: R.W. Sheard (ed.). Proc. 4th Intl. Turfgrass Res. Conf., 20 Univ. of Geulph, Ontario, Canada.

5. Dudeck, A.E. and C.H. Peacock. 1985. Tifdwarf bermudagrass growth response to carboxin and $\mathrm{GA}_{3}$ during suboptimum temperatures. Hortscience 20:936-938.

6. Dunn, J.H. and C.J. Nelson. 1974. Chemical changes occurring in three bermudagrass turf cultivars in relation to cold hardiness. Agron. J. 66:28-31.

7. Guinn, G. 1981. Changes in sugars, starch, RNA, protein, and lipid-soluble phosphate in leaves of cotton plants at low temperatures. Crop Sci. $11: 262-265$.

8. Juska, F.V. and J.J. Murray. 1974. Performance of bermudagrass in the transition zone as affected by potassium and nitrogen, $p$.
149-154. In: E.C. Roberts (ed.). Proc. 2nd Intl. Turfgrass Res. Conf., Amer. Soc. Agron., Madison, Wis.

9. Kanan, S. and T. Matthew. 1970. Effects of growth substances on the absorption and transport of iron in plants. Plant Physiol. 45:206-209.

10. Karbassi, P., L.A. Garrard, and S.H. West. 1971. Effect of low night temperature on growth and amylolytic activities of two species of digitaria. Soil Crop Sci. Soc. Florida, Proc. 30:251255.

11. Lever, M. 1972. A new reaction for calorimetric determination of carbohydrates. Anal. Biochem. 47:273-279.

12. Levitt, J. 1980. Responses of plants to environmental stresses. In: T.T. Kozlowski (ed.). Physiological ecology. vol. 1. Academic, New York.

13. McCaslin, B.D. and C.E. Watson. 1977. Fertilization of common bermudagrass (Cynodon dactylon L.) with foliar applications of iron. New Mexico Agr. Expt. Sta. Res. Rpt. 334.

14. Muller, K. and A.C. Leopold. 1966. The mechanism of kinetin induced transport in corn leaves. Planta 68:186-205.

15. Parker, J, 1962. Relationships among cold hardiness, water-soluble protein, anthocyanins, and free sugars in Hedera helix L. Plant Physiol. 37:809-813.

16. Reeves, S. A., Jr., G.G. McBee, and M.E. Bloodworth. 1970. Effect of N, P, and K tissue levels and late fall fertilization on the cold hardiness of tifgreen bermudagrass (Cynodon dactylon x C. transvaalensis). Agron. J. 62:659-662.

17. Rogers, R. A., J.H. Dunn, and C.J. Nelson. 1977. Photosynthesis and cold hardening in zoysia and bermudagrass. Crop Sci. 17:727732.

18. Smith, D. 1969. Removing and analyzing total nonstructural carbohydrates from plant tissue. Wis. Agri. Expt. Sta. Res. Rpt. 41.

Snyder, V. and R.E. Schmidt. 1973. Some aspects of nitrogen and iron fertilization of bentgrass, p. 13 1-144. In: E. C. Roberts (ed.). Proc. 2nd Intl. Turfgrass Res Conf., Amer. Soc. Agron., Madison. Wis.

20. Teng, J.L. and W.L. Pritchett. 1970. Effects of season, night temperature, and potassium on the absorption and translocation of iron in centipede grass [Eremochloa ophiuroides (Munro.) Hack]. Bet. Gaz. 131:272-276.

21. White, R. H., and R.E. Schmidt. 1989. Bermudagrass response to chilling temperatures as influenced by iron and benzyladenine. Crop Sci. 29:768-773.

22. Wolf, D.D. and T.L. Ellmore. 1973. Total nonstructural carbohydrates in forages by semiautomated analysis. Can. J. Plant Sci. 53:551-552.

23. Youngner, V.B. 1959. Growth of U-3 bermudagrass under various day and night temperatures and light intensities. Agron. J. 51:557-559. 